\title{
In Vitro Evaluation of Anti-RSV Activity of Centaurea Kotschyi (Boiss et Heldr.) Hayek Var. Decumbens Wagenitz
}

\author{
Onur Dombekci (Corresponding author) \\ Selcuk University, Faculty of Science, Department of biology, Konya Turkey \\ E-mail:onur.dombekci@gmail.com \\ Rustem Duman \\ Selcuk University, Faculty of Science, Department of biology, Konya Turkey \\ E-mail: rduman@selcuk.edu.tr
}

This work was financially supported by the Selcuk University Scientific Research Projects Coordinator ship (Project number: 17201125).

\begin{abstract}
This study was conducted to investigate the anti-RSV activities of crude methanol and aqueous extracts prepared from Centaurea kotschyi (Boiss. Et Heldr.) Hayek var. decumbens Wagenitz plant species grown in Turkey. Extracts were tested by means of the colorimetric XTT assay. The EC50 was defined as the concentration required to achieve $50 \%$ protection against virus-induced cytopathic effects, and the selectivity index (SI) was determined as the ratio of CC50 (concentration of $50 \%$ cellular toxicity) to EC50. Results showed that methanol extract of Centaurea kotschyi var. decumbens (EC50: $27.10 \mu \mathrm{g} / \mathrm{ml}$ and SI: 25.31) and its aqueous extract (EC50: $22.00 \mu \mathrm{g} / \mathrm{ml}$ and SI: 40.96) had anti-RSV activity in comparable rates to ribavirin $(\mathrm{EC} 50=4.19 \mu \mathrm{g} / \mathrm{ml}, \mathrm{SI}=27.92)$ used as a positive control against RSV. The cell cytotoxicity test showed that both of the extracts tested had higher CC50 values than the EC50 values. As a result, we can say that both extracts deserve further study in order to be developed as an alternative to ribavirin that is commonly used clinically against RSV. This work is the first report for anti-RSV activity of Centaurea kotschyi var. decumbens.
\end{abstract}

Keywords: Centaurea kotschyi var. decumbes, methanolic extract, anti-RSV activity.

DOI: $10.7176 / \mathrm{JSTR} / 5-5-11$

\section{Centaurea Kotschyı (Boiss et Heldr.) Hayek Var. Decumbens Wagenıtz'in In Vitro Anti-RSV Aktivitesinin Değerlendirilmesi}

\begin{abstract}
Özet
Bu çalışma, Türkiye'de yetişen Centaurea kotschyi (Boiss. Et Heldr.) Hayek var. decumbens Wagenitz bitki türünden hazırlanan kaba metanol ve su ekstraktlarının anti-RSV aktivitesini incelemek amacıyla yapılmıștr. Ekstraktlar kolorimetrik XTT testi aracılığıyla test edilmiştir. Virusun neden olduğu sitopatik etkilere karş1 \%50 koruma sağlayan konsantrasyon EC50 olarak tanımlanmış ve \%50 hücresel sitotoksisite konsantrasyonunu gösteren CC50'nin EC50'ye oranı olarak da seçicilik indeksi (SI) belirlenmiştir. Test sonuçları, Centaurea kotschyi var. decumbens metanol ekstraktının (EC50: 27.10 $\mu \mathrm{g} / \mathrm{ml}$ and SI: 25.31) ve su ekstraktının (EC50: $22.00 \mu \mathrm{g} / \mathrm{ml}$ and SI: 40.96) RSV'ye karşı pozitif kontrol olarak kullanılan ribavirin $(\mathrm{EC} 50=4.19 \mu \mathrm{g} / \mathrm{ml}, \mathrm{SI}=27.92)$ ile mukayese edilebilir oranlarda anti-RSV aktiviteye sahip olduğunu ortaya koymuştur. Hücre sitotoksisite testi, test edilen ekstraktların her ikisinin de, EC50 değerlerinden daha yüksek CC50 değerlerine sahip olduğunu göstermiş̧tir. Sonuç olarak, her iki ekstraktın da RSV'ye karşı klinikte yaygın olarak kullanılan ribavirine karşı alternatif olarak geliştirilebilmeleri için daha ileri çalı̧̧malara layık olduğunu söyleyebiliriz. Bu çalışma, Centaurea kotschyi var. decumbens' in anti-RSV aktivitesine yönelik ilk rapordur.
\end{abstract}

Anahtar Kelimeler: Centaurea kotschyi var. decumbens, metanol ekstraktı, anti-RSV aktivite. 


\section{Giriş}

Virusların neden olduğu akut respiratuvar enfeksiyonlar, dünyanın her yerinde çocuklarda morbidite ve mortalitenin başlıca sebebidirler. Respiratory syncytial virus (Respiratuvar sinsityal virus, RSV), bebeklerde, genç çocuklarda ve hatta erişkinlerde bile pnömoni ve bronşiyolitin en önemli sebebidir(Treanor ve Falsey, 1999). RSV, bağışıklığı baskılanmış popülasyonlarda tahripkar da olabilmektedir(Wyde ve ark., 1998). Ayrıca, tekrarlayan enfeksiyonlar, doğal olarak kazanılmış immunitenin uzun süreli koruma sağlamadığını gösteren yaygın bir olgudur(Dubovi ve ark., 1981). RSV'ye etkili aşı geliştirme girişimleri başarısız olmuştur(Wyde ve ark., 1998). Kaldı ki, bu aşılardan birisi kabul görse bile, bu aşı, RSV'ye duyarlı bazı populasyonlarda, örneğin, çok küçük bebeklerde ve bağışıklığı baskılanmış bireylerde uygun olmayabilmektedir (Wyde ve ark., 1998). Ribavirin (RBV) ve yüksek titreli RSV-spesifik nötralizan antikorları içeren immunglobulinler, günümüzde RSV enfeksiyonlarının tedavisi ve önleminde kullanımları kabul görmüş antivirallerdir (Kneyber ve ark., 2000). Bununla birlikte, bunların her ikisi de ucuz ve tatbiki kolay olmayan preparatlardir. RBV'nin intravenöz yolla verildiğinde miyelositotoksik olduğu bildirilmiş ve bu nedenle de sadece küçük aerosol partiküller halinde kullanımına izin verilmiştir(Smith ve ark., 1991). İlaçların hastalara, özellikle bebeklere ve çocuklara aerosol uygulanması, evde beceriyle kullanılması ve kontrolü bakımından oldukça güçlük göstermekte ve bu nedenle de hastaların kemoterapi için hastanelere gitmesi gerekmektedir. RSV'nin önlemi için kullanılabilir aşının olmayışı ve sadece şiddetli enfeksiyonlarda kullanılan tek bir antiviral etkenin (ribavirin) bulunması, çocuk hekimliğinde hala sorun teşkil etmektedir. Bu yüzden, oral veya parental olarak uygulanabilen özgün anti-RSV ilaçların geliştirilmesi gerekmektedir(Ma ve ark., 2002). Doğal ürünlerin öncü moleküllerin önemli bir kaynağı olduğu kanıtlanmış ve antiviral aktivitesi olan bitki orijinli pek çok ekstrakt ve bileşik bildirilmiştir (Kitazato ve ark., 2007).

Türkiye'de yetişen bitkilerin büyük çeşitliliği, doğal bir kaynaktan özgün antiviral bileşikler bulma konusunda ilginç firsatlar sunmaktadır. Centaurea L. (Asteraceae) cinsi, bütün Anadolu yarımadasına yayılmış, \% 61'i endemik olan, Türkiye florasındaki yaklaşık 181 türü içine almaktadır(Wagenitz, 1975) ve farmakolojik yönden son derece ümit vericidir. Centaurea türleri halk hekimliğinde tek başına veya diğer bitkilerle birlikte antidiyabetik, antidiyareik, antiromatizmal, antienflamatuvar, kolagog, koleretik, dijestif, stomaşik, diüretik, adet söktürücü, astrenjan, hipotonsif, antipiretik, sitotoksik, antibakteriyel amaçlarla kullanılmaktadır(Orallo ve ark., 1998). C. pulchella, C. drabifolia ve C. solstitialis' in Türk halk hekimliğinde çıbanları, hemoroidleri, peptik ülserleri, soğuk algınlığını ve en önemlisi çocukların dudakları etrafındaki herpes infeksiyonların tedavi etmede kullanıldığı bildirilmektedir(Sezik ve ark., 2001). Centaurea türlerinin kimyasal bileşimi üzerinde yapılan araştırmalar sonucunda bu türlerin flavonoit ve seskiterpen laktonlar bakımından zengin bir içeriğinin bulunduğu saptanmıştır. Bunların yanı sıra antosiyaninler, aromatik asitler, fitosteroller, alkaloitler gibi değişik yapılara da rastlamak mümkündür(Aslan ve Öksüz, 1999). Centaurea türlerinin antifungal(Skaltsa ve ark., 2000), antibakteriyel(Yeşilada ve ark., 1999), sitotoksik(Lonergan ve ark., 1992), antipiretik(Akbar ve ark., 1995), antimalaryal(Sathiyamoorthy ve ark., 1999), antiülserojenik(Yeşilada ve ark., 1993; Yeşilada ve ark., 1999), hipoglisemik(Ivorra ve ark., 1990) ve antifitoviral(Rusak ve ark., 1997) etkilerine dair çok sayıda araştırma bulunmasına rağmen, antiviral(Özçelik ve ark., 2009; Uzuncar ve Duman, 2016) etkileri hususunda çok az sayıda araştırma bulunmakta, RSV'ye karşı antiviral etkileri konusunda ise hiç çalışma bulunmamaktadır.

Ülkemizde önemli bir yeri olan Centaurea cinsinin değişik kısımlarının gerek halk arasındaki kullanılışı ve gerekse literatürlerde belirtilen ulusal ve uluslararası bir çok biyolojik aktivite çalışmalarının yapılmış olması göz önüne alınacak olursa, Türkiye'ye endemik bir Centaurea türü olan Centaurea kotschyi var. decumbens'den yeni antiviral bileşikler geliştirme konusunda yararlanılabileceği anlaşılmaktadır. $\mathrm{Bu}$ çalışma, Centaurea kotschyi var. decumbens'den elde edilen metanol ve su ekstraktlarının RSV'ye karşı antiviral aktivitesini değerlendirmek amacıyla yapılmıştır. Tıbbi bitkilerden biri olan Centaurea L., Asteraceae familyasına ait bir cinstir ve Türkiye'de \% 61'i endemik olan 181 türü vardır(Wagenitz, 1975). Bitki, peygamber çiçeği, zerdali dikeni, çoban kaldıran, Timur dikeni gibi Türkçe isimlerle bilinmektedir(Wagenitz, 1975). C. pulchella, C. drabifolia ve C. solstitialis' in Türk halk hekimliğinde apseleri, hemoroidleri, peptik ülserleri ve soğuk algınlığını tedavi etmede kullanıldığı bildirilmektedir(Sezik ve ark., 2001). Centaurea'nın bileşenleri esas olarak flavonoidler(Akkal ve ark., 2003), lignan glikozitler(Gousiado ve Skaltsa, 2003) ve son zamanlarda dahil edilen seskiterpen laktonlardır(Özçelik ve ark., 2009). Centaurea türlerinin biyolojik aktiviteleriyle ilgili çok sayıda araştırma yapılmıştır. Yapılan bu araştırmalarla; Centaurea' ların antiviral(Özçelik ve ark., 2009; Uzuncar ve Duman, 2016), antifitoviral(Rusak ve ark., 1997), antifungal(Skaltsa ve ark., 2000), antibakteriyel(Yeşilada ve ark., 1999), sitotoksik(Koukoulitsa ve ark., 2002), antiplazmodiyal(Medjroubi ve ark., 2005) aktiviteleri olduğu gösterilmiştir. 
Rusak, Krajacic ve Plese(Rusak ve ark., 1997), C. rupestris'in çiçek ve yaprak ekstrelerinin yanı sıra bu ekstrelerden izole ettikleri kersetagenin-3'-metileter'in antifitoviral etkilerini Tomato Bushy Stunt Virus (TBSV)'u ile enfekte edilmiş iki Nicotiana türü üzerinde incelemişlerdir. İnceleme sonucunda; flavonoitlerin, virus enfeksiyonunun başlamasını engelleyerek antifitoviral aktivite gösterebileceğini tespit etmişlerdir. Özçelik, Gürbüz, Karaoğlu ve Yeşilada(Özçelik ve ark., 2009), Centaurea solstitialis L. ssp. solstitialis (Asteraceae)'den izole ettikleri üç seskiterpen laktonun (centaurepensin, klorojanerin ve 13-asetil solstitialin A) HSV-1 ve Parainfluenza virus (PIV)'una karș1 antiviral etkilerini araştırmışlardır. Araştırma sonucunda; 13 -asetil solstitialin A'nın 16 ve $0.00006 \mu \mathrm{g} / \mathrm{ml}$ 'lik maksimum ve minumum konsantrasyon değerleriyle referens etken asiklovir (ACV) ile aynı oranda HSV-1'e karşı antiviral aktivitesi olduğunu tespit etmişlerdir. Uzuncar ve Duman(Uzuncar ve Duman, 2016) tarafindan yapılan bir çalışmada, C. kotschyi var. decumbens'den elde edilen metanol ve su ekstraktlarının HSV1'e karşı, sırasıyla, 3.63 ve 1.25 seçicilik indeksleriyle antiviral etkiye sahip olduğu gösterilmiştir. Bebekler, küçük çocuklar ve yetişkinlerde alt solunum sistemi enfeksiyonlarının en önemli sebebi RSV'dir(Falsey ve Walsh, 2000). RSV bir yaşından küçük bebeklerde solunum sisteminin en önemli viral patojenidir(Collins ve Crowe, 2007). RSV enfeksiyonu ve reenfeksiyonu yaşamın ilk birkaç y1lı sırasında sık görülmektedir(Collins ve Crowe, 2007). Bu nedenle, 24 ay boyunca enfekte kalan çocuklar, hemen hemen iki enfeksiyona da maruz kalmışlardır(Collins ve Crowe, 2007). Etkili tedavi yöntemlerine oldukça fazla ihtiyaç duyulmaktadır. Bununla birlikte, RSV'nin neden olduğu şiddetli alt solunum yolu enfeksiyonunu kontrol etmek amaciyla sadece destekleyici tedavi uygulanmaktadir(Collins ve Crowe, 2007). RBV, inosin monofosfat (IMP) dehidrojenazın inhibitörü olan bir guanozin analoğudur. RBV, viral transkripsiyondaki erken olayları engellemekte ve ribonükleoprotein sentezini inhibe etmektedir(Wray ve ark., 1985). RBV deneysel olarak enfekte edilen hayvanlarda etkili olmasına rağmen, RSV tedavisinde çok az etki göstermiştir(Collins ve Crowe, 2007). Palivizumab (Synagis) RSV enfeksiyonunun önlenmesinde etkilidir(Collins ve Crowe, 2007). Ancak, çok masraflıdır ve varolan bir enfeksiyonun tedavisinde etkili değildir(Collins ve Crowe, 2007). Bu nedenle, etkili kemoterapötik ajanlara hala acil olarak ihtiyaç duyulmaktadır(Wray ve ark., 1985).

\section{Gereç ve Yöntem}

\subsection{Bitki materyali}

Anti-RSV aktiviteleri yönünden araştırılmış olan Centaurea kotschyi (Boiss. Et Heldr.) Hayek var. decumbens Wagenitz örnekleri, 2017 yllının Temmuz-Ağustos aylarında, özellikle bitki türlerinin çiçeklendiği aylarda, araziye çıkılmak suretiyle toplanmış ve(Davis, 1975)' in "Flora of Turkey and the East Aegean Islands" adlı eserinden faydalanılarak Selçuk Üniversitesi, Fen Fakültesi, Biyoloji Bölümü Herbaryumu'nda teşhis edilmişlerdir. Centaurea kotschyi toprak üstü kısımları gölgede kurutulmuş, bir değirmen aracıllğıyla ince toz halinde ögütülmüş ve steril siyah cam kavanozların içerisinde oda sıcaklığında muhafaza edilmişlerdir. Bitkinin kanıt numuneleri S. Ü. Fen Fakültesi, Biyoloji Bölümü Herbaryumu'nda saklanmaktadır.

\subsection{Hücre ve virus}

Bütün deneylerde konak hücre olarak insan respiratuvar sinsityal virusu (human respiratory syncytial virus: HRSV, ATCC-VR-26)'nün duyarlılık gösterdiği insan epidermoid larinks karsinom (Hep-2, ATCC-CCL-23) hücre serisi kullanılmıştır. Hep-2 hücreleri ve HRSV, S. Ü. Fen Fakültesi Biyoloji Bölümü Viroloji Laboratuvarı'ndan temin edilmiştir.

\subsection{Ekstraktların hazırlanmasl}

Antiviral aktivitesi yönünden araştrılan Centaurea kotschyi var. decumbens'e ait örneklerin toprak üstü kısımları bir firında $\left(40^{\circ} \mathrm{C}\right) 8$ saat tutularak kurutulmuştur. Kurutulan bitki materyalleri değirmende ögütülerek toz haline getirilmiştir. Toz halindeki bitki materyalinden 10'ar g tartılarak ayrı ayrı $250 \mathrm{ml}$ ultra saf su ve $250 \mathrm{ml}$ metanolün içerisine konulmuş ve $25-37^{\circ} \mathrm{C}$ sıcaklıkta ultrasonik homojenizatör cihazı (Bandelin SONOPULS MS73) ile 1 saat ultrasonikasyona tabi tutulmuşlardır. Protokol sırasında örneklerdeki fitokimyasalların sıcaklıktan dolayı bozulmasını önlemek amacıyla sıcaklığın $40^{\circ} \mathrm{C}$ 'nin altında tutulmasına özellikle dikkat edilmiştir. Metanol ekstraktlarının $35-40^{\circ} \mathrm{C}$ 'de $200-250$ rpm'e ayarlanan rotary evaporatörde (IKA RV10) çözz̈cüleri tamamen uçurulmuştur. Evaporasyon işleminden sonra ekstraktlar $-80 \mathrm{oC}^{\prime}$ de (NEW BRUNSWICK SCIENTIFIC-U410 premium) dondurulmuştur. Dondurulmuş ekstraktlar liyofilizasyon cihazı (SCANVAC) ile $-110^{\circ} \mathrm{C}$ 'de 2 gün boyunca bekletilerek kurutulmuştur. Liyofilize haldeki metanol ve su ekstraktının her 1000 mg' $10 \mathrm{ml}$ EMEM (serumsuz) içinde çözdürülerek $100 \mathrm{mg} / \mathrm{ml}$ konsantrasyonunda stok solüsyonlar hazırlanmıştır. Stok solüsyonlar $0.22 \mu \mathrm{m}$ 'lik milipor filtreden geçirilerek steril edilmiş ve $2 \mathrm{ml}$ 'lik tüplere 1 'er $\mathrm{ml}$ bölüştürülerek, kullanılıncaya kadar $+4{ }^{\circ} \mathrm{C}$ 'de saklanmıştır. Sitotoksisite ve antiviral aktivite testlerinde kullanılacak ekstrakt dilüsyonları bu stoklardan hazırlanmıştır.

İnsanlarda RSV enfeksiyonlarının tedavisi için onaylanmış bir ilaç olan ribavirin (RBV, R9644-10 mg,

101 | P a g e

www.iiste.org 
Sigma, USA) ticari olarak sağlanmıştır. Steril bir deney tüpünün içerisine toz halindeki ribavirinden 5 $\mathrm{mg}$ konulduktan sonra, üzerine $5 \mathrm{ml}$ EMEM (serumsuz) eklenmiştir. Elde edilen $1000 \mu \mathrm{g} / \mathrm{ml}$ konsantrasyonundaki süspansiyon $0,2 \mu \mathrm{m}$ por çapındaki milipor filtreden geçirilerek $10 \mathrm{ml}$ 'lik şişeye süzülmüş ve $1 \mathrm{dk}$ süreyle vorteksle karıştırılmıştır. Stok solüsyon deneylerde kullanılıncaya kadar $80^{\circ} \mathrm{C}$ 'da saklanmıştır $\left(+4^{\circ} \mathrm{C}\right.$ 'da saklandığında, 1 hafta içinde kullanılmıştır $)$.

2.4. Sitotoksisite testi

Hücre canlılık testinin kriter olarak alındığı ekstraktların ve RBV'nin sitotoksik etkilerini belirlemede, kolorimetrik XTT metodu(Eskiocak ve ark., 2008) kullanılmıştır. Test, özetle şöyle uygulanmıştır: 96 kuyucuklu bir mikropleytin 1. kolonu besiyeri kontrol (BK), 2. kolonu hücre kontrol (HK) olarak kullanılmıştır. BK olarak kullanılan 1. kolondaki 8 adet kuyucuğun her birine $100 \mu$ l EMEM (serumsuz) $+50 \mu 1 \% 10$ FBS'li EMEM konulmuştur. 3. kolon hariç, geriye kalan 10 kolondaki (yani, 2, 4, 5, 6, 7, 8, 9, 10, 11 ve 12. kolondaki) kuyucukların her birine 100'er $\mu 1$ EMEM (serumsuz) konulmuştur. Ekstraktların stok solüsyonundan $(100 \mathrm{mg} / \mathrm{ml}) 75 \mathrm{mg} / \mathrm{ml}$ konsantrasyonda bir çalışma solüsyonu hazırlanmıştır (toplam $2 \mathrm{ml}$ ). Bu amaçla, ekstraktların stok solüsyonundan $1.5 \mathrm{ml}$ alınmış ve üzerine 0.5 ml EMEM (serumsuz) konulmuştur. 3. kolonda bulunan 8 adet kuyucuğun her birine ekstraktların çalışma solüsyonundan $(75 \mathrm{mg} / \mathrm{ml}) 200 \mu 1$ konulmuştur. 8 kanallı otomatik bir pipet ile 2 . kolondaki kuyucuklardaki çalıșma solüsyonundan 100 'er $\mu$ l alınıp 3. kolondaki kuyucuklara 100'er $\mu 1$ taşınmıștır. Daha sonra 3. kolondaki kuyucuklarda yer alan ekstrakt sulandırmalarından 100'er $\mu$ l alınıp, 4. kolondaki kuyucuklara 100 'er $\mu \mathrm{L}$ taşınmıştır. Taşıma işlemleri 12. kolondaki kuyucuklara kadar devam ettirilerek $\log 2$ tabanına göre sulandırmalar $(75.00,37.50,18.75,9.38,4.69,2.34,1.17,0.59,0.29,0.15 \mathrm{mg} / \mathrm{mL})$ hazırlanmıştır. Aynı işlemler, başka bir mikropleyt kullanılarak RBV için de uygulanmıştır. İlk önce, RBV'nin stok solüsyonundan $(1000 \mu \mathrm{g} / \mathrm{ml}) 750 \mu \mathrm{g} / \mathrm{ml}$ konsantrasyonda bir çalışma solüsyonu hazırlanmıştır (toplam $2 \mathrm{ml}$ ). Bu amaçla, RBV'nin stok solüsyonundan $1.5 \mathrm{ml}$ alınmış ve üzerine $0.1 \mathrm{ml}$ serumsuz EMEM konulmuştur. 3. kolonda bulunan 8 adet kuyucuğun her birine RBV'nin çalışma solüsyonundan $(750 \mu \mathrm{g} / \mathrm{ml}) 200 \mu \mathrm{l}$ konulmuştur. 8 kanallı otomatik bir pipet ile 2 . kolondaki kuyucuklardaki stok solüsyonlardan 100'er $\mu$ l alınıp 3. kolondaki kuyucuklara 100'er $\mu 1$ taşınmıştır. Daha sonra 3. kolondaki kuyucuklarda yer alan RBV sulandırmalarından 100'er $\mu 1$ alınıp, 4. kolondaki kuyucuklara 100 'er $\mu 1$ taşınmıştır. Taşıma işlemleri 12. kolondaki kuyucuklara kadar devam ettirilerek $\log 2$ tabanına göre sulandırmalar $(750.00,375.00,187.50,93.75,46.88,23.44,11.72,5.86,2.93,1.46$ $\mu \mathrm{g} / \mathrm{ml}$ ) hazırlanmıştır. 2 dahil 12'ye kadar olan kolonlardaki kuyucukların her birine mililitresinde $1 \times$ 105 hücre içeren HEp-2 hücre süspansiyonundan 50'şer $\mu 1$ konulmuştur (kuyucuk başına 5000 hücre). Mikropleytler 3 gün süreyle $\% 5 \mathrm{CO} 2$ 'li nemli bir inkübatörde $37^{\circ} \mathrm{C}$ 'de inkübe edildikten sonra, ticari olarak elde edilen XTT ayıracının 5 ml'si ile yine ticari olarak elde edilen PMS aktivatörünün 0.1 ml'sinin karıştırılmasıyla hazırlanan karışımdan her kuyucuğa 50'şer $\mu$ l konulmuştur. Mikropleytler, boyanın kuyucuklara homojen bir şekilde dağılması için hafifçe çalkalanmıştır. Mikropleytler, XTT formazan ürününün oluşması için 3 saat daha inkübe edilmiştir. Optik dansisite (OD)’ler, $490 \mathrm{~nm}$ bir test dalga boyu ve $630 \mathrm{~nm}$ bir referans dalga boyunda bir ELISA okuyucusunda (Multiskan EX, Labsystems) okutularak 8 kuyucuktan elde edilen OD ortalamaları kaydedilmiştir. Testler üç kopya olarak yapılmış ve sonuçlar hücre kontrole göre ortalama sitotoksisite \% oranı olarak gösterilmiştir. Sitotoksisite \% oranını hesaplamak için, A’nın hücre kontrolün OD’sini, B’nin ekstrakt (veya RBV) ile muamele edilmiş hücrelerin OD'sini temsil ettiği aşağıdaki formül kullanılmıştır(Andrighetti-Fröhmer ve ark., 2003):

Sitotoksisite $(\%)=\frac{(\mathrm{A}-\mathrm{B})}{\mathrm{A}} \times 100$

Hesaplanan sitotoksik etki yüzdeleri test edilen ekstraktların (veya RBV'nin) ilgili konsantrasyonlarına karşı grafiğe dönüştürülmüştür. HK'ler ile karşılaştırıldığında ekstraktlar (veya RBV) ile muamele edilmiş hücrelerin OD'sini \%50'ye kadar azaltan konsantrasyon olarak tanımlanan Sitotoksik Konsantrasyon50 (CC50) değerleri, elde edilen verilerin ışığında GraphPad Prism Version 5.03 istatistik programı yardımıyla non-linear regresyon analizi uygulanarak belirlenmiştir(Ho, 2008). HK'lerin OD'leri ile karşılaştırılarak ekstraktların (veya RBV'nin) MNTK (maksimum non-toksik konsantrasyon)'leri belirlenmiştir. Belirlenen bu MNTK'ler ekstraktların ve RBV'nin antiviral aktivitesinin saptanmasında kullanılmıştır.

2.5.Antiviral aktivite testi

Ekstraktların HEp-2 hücrelerine karşı belirlenen MNTK'lerinden 10 misli daha konsantre olacak şekilde hazırlanan sulandırmalarından başlamak üzere Log2 tabanına göre hazırlananan sulandırmaları RSV'ye karşı antiviral aktiviteleri yönünden XTT metodu(Chiang ve ark., 2003) ile 100 DKID50 oranında sulandırılmış virus dozuna karşı kontrol edilmiştir. Yöntem aşağıda tarif edildiği şekilde uygulanmıştır: Tripsin ile muamele edilen HEp-2 hücrelerinin \%2 FBS içeren EMEM (hücre idame besiyeri) kullanılarak 1 × 105 hücre/ml konsantrasyonda olacak şekilde süspansiyonları hazırlanmıştır. Hazırlanan 
bu hücre süspansiyonlarından 96 kuyucuklu kültür pleytlerinin kuyucuklarına (BK olarak kullanılan pleytin 8 kuyucuğu hariç) kuyucuk başına $70 \mu 1$ volümde (7000 hücre/kuyucuk) ekim yapılmıştır. $37^{\circ} \mathrm{C}$ 'de $\% 5 \mathrm{CO} 2^{\prime}$ li ortamda 24 saat inkübasyondan sonra, kuyucuklara (pleytin BK olarak kullanılan 1. kolonu ile HK olarak kullanılan 2. kolonundaki 8 kuyucuk hariç) idame besiyeri (\%2 FBS'li EMEM) kullanılarak 100 DKID50 / $0.1 \mathrm{ml}$ oranında sulandırılan RSV süspansiyonundan 20'şer $\mu 1$ konulmuştur. Mikropleytin 3. kolonundaki 8 adet kuyucuk Virus Kontrol (VK) olarak kullanılmıştır. Mikropleytin BK olarak kullanılan 1. kolonu ile HK olarak kullanılan 2. kolonundaki 8 adet kuyucuğa 20 'şer $\mu 1$ idame besiyeri konulmuş ve pleyt 2 saat daha inkübe edilmiştir. Ekstraktların stok solüsyonlarından (100 $\mathrm{mg} / \mathrm{ml}) \% 2$ FBS içerecek şekilde $10 \times$ MNTK'de sulandırmaları hazırlanmıştır (toplam $2 \mathrm{ml}$ ). Daha sonra, $10 \times$ MNTK'deki ekstrakt solüsyonlarından idame besiyeri kullanılarak seri halinde 2 misli sulandırmalar hazırlanmıştır (toplam 1'er ml). İki saatlik inkübasyon süresinden sonra, 96 kuyucuklu mikropleytlerin 4. kolonlarındaki 8'er kuyucuğa hazırlanan $10 \times$ MNTK'deki ekstrakt sulandırmalarından 10'ar $\mu 1$ konulmuştur. Mikropleytlerin geriye kalan 8 kolonundaki kuyucuklara (yani, $5,6,7,8,9,10,11$ ve 12 . kolonlardaki kuyucuklara) da ekstraktların $(10 \times \mathrm{MNTK}) / 2,(10 \times \mathrm{MNTK}) / 4$, $(10 \times \mathrm{MNTK}) / 8,(10 \times \mathrm{MNTK}) / 16,(10 \times \mathrm{MNTK}) / 32,(10 \times \mathrm{MNTK}) / 64,(10 \times \mathrm{MNTK}) / 128,(10 \times \mathrm{MNTK}) / 256$ konsantrasyonundaki sulandırmalarından 10'ar $\mu 1$ konulmuştur. Mikropleytlerin BK, HK ve VK olarak kullanılan kolonlarındaki kuyucuklarına da 10'ar $\mu$ lidame besiyeri konulmuştur. Aynı işlemler, başka bir mikropleyt kullanılarak RBV için de uygulanmıştır. RBV'nin stok solüsyonundan $(1000 \mu \mathrm{g} / \mathrm{ml}) \% 2 \mathrm{FBS}$ içerecek şekilde $10 \times$ MNTK'de bir sulandırması hazırlanmıştır. Daha sonra, $10 \times$ MNTK'deki RBV solüsyonundan idame besiyeri kullanılarak seri halinde 2 misli sulandırmalar $[(10 \times \mathrm{MNTK}) / 2$, $(10 \times$ MNTK $) / 4,(10 \times$ MNTK $) / 8,(10 \times$ MNTK $) / 16,(10 \times$ MNTK $) / 32,(10 \times$ MNTK $) / 64,(10 \times$ MNTK $) / 128$, $(10 \times$ MNTK $) / 256]$ hazırlanmıştır. Bundan sonra, ekstraktların antiviral aktivitesinin belirlenmesinde uygulanan basamaklar takip edilmiştir. Pleytlerin kapağ 1 kapatılmış ve $37^{\circ} \mathrm{C}$ 'de $\% 5 \mathrm{CO} 2^{\prime} l i$ ortamda 3 gün süreyle inkübe edilmişlerdir. İnkübasyondan sonra, ticari olarak elde edilen XTT ayıracının 5 ml'si ile yine ticari olarak elde edilen PMS aktivatörünün 0.1 ml'sinin karıştırılmasıyla hazırlanan karışımdan her kuyucuğa 50'şer $\mu 1$ konulmuştur. Boyanın kuyucuklara homojen bir şekilde dağılması için pleytler hafifçe çalkalanmıştır. XTT formazan ürününün oluşması için pleytler 2 saat daha inkübe edilmiştir. OD'ler, $490 \mathrm{~nm}$ test dalga boyu ve $630 \mathrm{~nm}$ referans dalga boylarında bir ELISA okuyusunda (Multiskan EX, Labsystems) okutularak 8 kuyucuktan elde edilen OD ortalamaları kaydedilmiştir. Farklı ekstrakt (veya RBV) konsantrasyonlarının virusa karşı koruma yüzde oranları, spektrofotometrik olarak aşağıdaki formülden hesaplanmıştır(Andrighetti-Fröhmer ve ark., 2003):

Koruma \%'si = [ (A-B) / (C-B) x 100$]$

Enfekte hücrelerin \% 50'sinde koruma sağlayan ekstrakt (veya RBV) konsantrasyonu olarak tanımlanan EC50 değeri, ekstrakt (veya RBV) konsantrasyonlarına karşı belirlenen koruma \% oranlarından yararlanılarak, GraphPad Prism Version 5.03 istatistik programı kullanılarak non-linear regresyon analiziyle belirlenmiştir. Ekstraktların seçicilik indeksi (SI) ise, CC50/EC50 oranından hesaplanmıştır. Deneyler 3 kez tekrarlanmıştır.

\section{Bulgular}

\subsection{Virus Titrasyonu}

Araştırmada kullanılan RSV'nin HEp-2 hücreleri kullanılarak gerçekleştirilen mikrotitrasyon testi sonucunda titresi, 3 . gün sonunda DKID50 $=10-4.5 / 0.1 \mathrm{ml}$ olarak saptanmıştır.

\subsection{Sitotoksisite Testi Sonuçları}

Bu çalışmada, Centaurea kotschyi (Boiss. Et Heldr.) Hayek var. decumbens Wagenitz'den elde edilen metanol ve su ekstraktları, kolorimetrik XTT testi ile RSV'ye karşı antiviral aktiviteleri yönünden incelenmiştir. Antiviral testlerin gerçekleştirilmesi için ön koşul olarak, virus-konakçı hücrelerine (RSV-HEp-2) karşı ekstraktların ve RSV'ye karşı pozitif kontrol olarak kullanılan RBV'nin sitotoksisiteleri kolorimetrik hücre canlılık testi ile araştırılmıştır. Centaurea kotschyi var. decumbens metanol ve su ekstraktlarının MNTK'leri sirasiyla $391 \mu \mathrm{g} / \mathrm{ml}$ ve $98 \mu \mathrm{g} / \mathrm{ml}$, CC50 değerleri ise sırasıyla $685.86 \mu \mathrm{g} / \mathrm{ml}$ ve $901.03 \mu \mathrm{g} / \mathrm{ml}$ olarak belirlenmiştir (Tablo 1).

RSV'ye karşı pozitif kontrol olarak kullanılan RBV'nin MNTK'sini ve CC50 değerini saptamak için 3 kopya halinde gerçekleştirilen test sonucunda hesaplanan sitotoksisite \% oranları Tablo 1'de gösterilmektedir. Ribavirin'in MNTK'si $0.98 \mu \mathrm{g} / \mathrm{ml}$, CC50 değeri ise $117 \mu \mathrm{g} / \mathrm{ml}$ olarak belirlenmiştir (Tablo 1).

3.3. Antiviral Aktivite Testi Sonuçları

Centaurea kotschyi var. decumbens metanol ve su ekstraktlarının EC50 değerleri, bu ekstraktların farklı konsantrasyonlarına karşı belirlenen koruma \% oranlarının grafiğe dönüştürülmesiyle, GraphPad Prism istatistik programı ile non-linear regresyon analizi uygulanarak uygulanmıştır. Centaurea kotschyi var. 
decumbens metanol ekstraktının EC50 değeri $27.10 \mu \mathrm{g} / \mathrm{ml}$, SI değeri 25.31 olarak tespit edilirken, Centaurea kotschyi var. decumbens su ekstraktının EC50 değeri $22.00 \mu \mathrm{g} / \mathrm{ml}$, SI değeri ise 40.96 olarak tespit edilmiştir (Tablo 1).

RBV'nin EC50 değeri, GraphPad Prism istatistik programı kullanılarak non-linear regresyon analiziyle $4.19 \mu \mathrm{g} / \mathrm{ml}$ olarak belirlenmiş, CC50'nin EC50'ye oranı olarak tanımlanan seçicilik indeksi (SI) ise, 27.92 olarak belirlenmiştir (Tablo 1).

\begin{tabular}{|l|l|l|l|l|l|}
\hline Bitki Türü & \multirow{2}{*}{$\begin{array}{l}\text { Ekstrakt } \\
\text { Türü }\end{array}$} & \multicolumn{2}{|l|}{ Toksisite } & \multicolumn{2}{|l|}{$\begin{array}{l}\text { Antiviral } \\
\text { aktivite }\end{array}$} \\
\cline { 3 - 6 } & & $\begin{array}{l}\text { MNTK } \\
(\mu \mathrm{g} / \mathrm{ml})\end{array}$ & $\begin{array}{l}\text { CC50 } \\
(\mu \mathrm{g} / \mathrm{ml})\end{array}$ & $\begin{array}{l}\text { EC50 } \\
(\mu \mathrm{g} / \mathrm{ml})\end{array}$ & SI \\
\hline $\begin{array}{l}\text { Centaurea kotschyi var. } \\
\text { Decumbens }\end{array}$ & Metanol & 391 & 685.86 & 27.10 & 25.31 \\
\cline { 2 - 6 } & Su & 98 & 901.03 & 22.00 & 40.96 \\
\hline RBV & & 0.98 & 117.00 & 4.19 & 27.92 \\
\hline
\end{tabular}

Tablo 1. Centaurea kotschyi var. decumbens metanol ve su ekstraktlarının sitotoksisite ve antiviral aktivite deneyleri toplu sonuçları

RBV: Ribavirin

MNTK: Maksimum Non-Toksik Konsantrasyon

CC50: \% 50 hücre toksisitesinin konsantrasyonu

EC50: Enfekte hücrelerin \% 50'sinde koruma sağlayan konsantrasyon

SI: Seçicilik indeksi

\section{Tartışma}

RSV, üst solunum mukozasını enfekte edebilmekte ve başlangıçta nazofarenkste replike olabilmektedir. RSV muhtemelen sekresyonların aspirasyonu ile alt solunum sistemine hızla yayılabilmektedir. RSV esas olarak alt solunum yollarının patolojisi ile morbidite ve mortaliteye neden olmaktadır. Bu nedenle, RSV enfeksiyonunun yönetimi hem üst hem de alt solunum yollarının viral enfeksiyonunu engellemek için etkili bir stratejiye ihtiyaç duymaktadır(Collins ve Crowe, 2007).

$\mathrm{Bu}$ çalışma, Centaurea kotschyi var. decumbens'den hazırlanan metanol ve su ekstraktlarının insan üst solunum sistemi hücrelerinde (HEp-2) RSV'nin neden olduğu sitopatik etkilerin inhibe edilmesinde RSV enfeksiyonlarının tedavisinde kullanılan standart ilaç RBV ile eşdeğer hatta daha etkili olduğunu göstermiştir. Tablo 1' de görüldüğü gibi, Centaurea kotschyi var. decumbens metanol ve su ekstraktlarının EC50 değerleri sırasıyla $27.10 \mu \mathrm{g} / \mathrm{ml}$ ve $22.00 \mu \mathrm{g} / \mathrm{ml}$ olarak tespit edilirken, SI değerleri sirasıyla 25.31 ve 40.96 olarak tespit edilmiştir. RBV'nin EC50 ve SI değerleri ise sırasıyla $4.19 \mu \mathrm{g} / \mathrm{ml}$ ve 27.92 olarak tespit edilmiştir. Ekstraktların HEp-2 hücreleri üzerine RSV enfeksiyonlarına karşı standart ilaç olarak kullanılan RBV'den daha az toksik olduğu, ekstraktlar ve RBV'nin CC50 değerlerinin EC50 değerlerinden daha yüksek olduğu dikkat çekmektedir. Bu durum, antiviral bir ajanın güvenirliği bakımından önemlidir(Schinazi ve ark., 2009). Ayrıca yapılan bir araştırmada, 10 ve 10'dan büyük SI değerlerinin test ekstraktlarının potansiyel olarak güvenilir antiviral aktivitesinin göstergesi olarak kabul edilmesi gerektiği bildirilmiştir(Chattopadhyay ve ark., 2009).

Yapılan bu çalışma dışında, Centaurea türlerine ait ekstrakt ve bileşenlerin anti-RSV aktivitelerinin değerlendirildiği hiçbir çalışma bulunmamakta, diğer DNA ve RNA viruslarına karş1 antiviral aktivitelerin değerlendirilmesine yönelik ise çok az çalışma bulunmaktadır(Rusak ve ark., 1997; Özçelik ve ark., 2009; Uzuncar ve Duman, 2016).

(Ertugrul ve ark., 2003) yaptıkları çalı̧̧mada, Centaurea kotschyi var. decumbens'in uçucu yağının temel bileşenlerinin seskiterpenler olduğu tespit edilmiştir. Yine değişik Centaurea türlerinin kimyasal bileşimi üzerinde yapılan araştırmalar sonucunda bu türlerin flavonoit ve seskiterpen laktonlar bakımından zengin bir içeriğinin bulunduğu saptanmıştır. Bunların yanı sıra antosiyaninler, aromatik asitler, fitosteroller, alkaloitler gibi değişik kimyasal yapılara da rastlamak mümkündür(Aslan ve Öksüz, 1999). Yapılan çalışmalar flavonoitlerin anti-RSV etkileri yanında(Shang ve ark., 2001), antifitoviral etkilere de sahip olduğunu ortaya koymuştur(Rusak ve ark., 1997). Çalışmamızın materyalini teşkil eden Centaurea kotschyi var. decumbens'den elde edilen ekstraktların RSV'ye karşı yüksek derecede antiviral etkiye sahip olması, her ne kadar bu türün kimyasal bileşenlerini ortaya koyan kapsamlı bir çalışma olmasa da, diğer Centaurea türlerinin özellikle flavonoitler bakımından zengin olduğu göz önüne alınarak, 
Centaurea kotschyi var. decumbens'de bulunabilecek başta flavonoitler olmak üzere diğer bileşenlerin varlığına bağlanabilir.

\section{Sonuç ve Öneriler}

Yapılan bu çalışmada, kolorimetrik XTT testi ile anti-RSV aktiviteleri yönünden test edilen Centaurea kotschyi var. decumbens türüne ait metanol ve su ekstraktlarının pozitif kontrol olarak kullanılan RBV ile eşdeğerde hatta daha da yüksek sayılabilecek anti-RSV aktiviteye sahip olduğu ortaya konulmuştur. Ancak, ekstraktların kimyasal kompozisyonlarının tespit edilerek elde edilen saf bileşiklerin teste tabi tutulmamasının doğru ve güvenilir sonuçlar elde edilmesi bakımından önemli bir eksiklik olduğu da bir gerçektir. Bu nedenle, bundan sonra yapılacak araştırmalarda bu eksiklikler giderilerek, aynı türe ait ekstraktlarda anti-RSV aktiviteden sorumlu bileşikler ve bu bileşiklerin antiviral etki mekanizmaları tespit edilmeye çalışılabilir.

\section{Kaynaklar}

Akbar, S., Fries, D. S., \& Malone, M. H. (1995). Effect of various pretreatments on the hypotermic activity of repin in naive rats. Journal of Ethnopharmacology, 49(2), 91-99.

Akkal, S., Benayache, F., Medjroubi, K., Tillequin, F., \& Seguin, E. (2003). Flavonoids from Centaurea furfuracea (Asteraceae). Biochemical Systematics and Ecology, 31, 641-643.

Andrighetti-Fröhmer, C. R., Antonio, R. V., Creczynski-Pasa, T. B., Barardi, C. R. M., \& Simões, C. M. O. (2003). Cytotoxicity and potential antiviral evaluation of violacein produced by Chromobacterium violaceum. . Memórias do Instituto Oswaldo Cruz, 98, 843-848.

Aslan, Ü., \& Öksüz, S. (1999). Chemical constituents of Centaurea cuneifolia. . Turkish Journal Of Chemistry, 23(1), 15-20.

Chattopadhyay, D., Chawla-Sarkar, M., Chatterjee, T., \& etal. (2009). Recent advancements for the evaluation of antiviral activities of natural products. . New Biotechnology, 25, 347-368.

Chiang, L. C., Cheng, H. Y., Liu, M. C., Chiang, W., \& Lin, C. C. (2003). In vitro anti-herpes simplex viruses and anti-adenoviruses activity of twelve traditionally used medicinal plants in Taiwan. . Biological and Pharmaceutical Bulletin, 26, 1600-1604.

Collins, P. L., \& Crowe, J. E. (2007). Respiratory syncytial virus and metapneumovirus. . In D. M. Knipe, P. M. Howley, D. E. Griffin, \& etal. (Eds.), Fields Virology (pp. 1601-1646). Philadelphia: Lippincott Williams \& Wilkins

Davis, P. H. (1975). Flora of Turkey and The East Aegean Islands. (Vol. 5). Centaurea LEdinburgh: Edinburgh University Press.

Dubovi, E. J., Geratz, J. D., Shaver, S. R., \& Tidwell, R. R. (1981). Inhibition of respiratory syncytial virus-host cell interactions by monoand diamidines. . Antimicrobial Agents and Chemotherapy, 19, 649-656.

Ertugrul, K., H., D., Tugay, O., Flamini, G., Cioni, P. L., \& Morelli, I. (2003). Essential oils from flowers of Centaurea kotschyi var. kotschyi and C. kotschyi var. decumbens from Turkey. . Flavour and Fragrance Journal, 18, 95-97.

Eskiocak, U., İşeri, O. D., Kars, M. D., Biçer, A., \& Gündüz, U. (2008). Effect of doxorubicin on telomerase activity and apoptotic gene expression in doxorubicin-resistant and -sensitive MCF-7 cells: an experimental study. Chemotherapy, 54, 209-216.

Falsey, A. R., \& Walsh, E. E. (2000). Respiratory syncytial virus infection in adults. . Clinical Microbiology Reviews, 13, 371-384. 
Gousiado, C., \& Skaltsa, H. (2003). Secondary metabolites from Centaurea orphanidea. . Biochemical Systematics and Ecology, 31, 389-396.

Ho, W. S. (2008). Antiviral Activity of the Medicinal Plants, Adina pilulifera, Narcissus tazetta and Wikstroemia indica, against Respiratory Syncytial Virus. .

Ivorra, M. D., D'ocon, M. P., Paya, M., \& Villar, A. (1990). Effect of $\beta$-sitosterol 3- $\beta$-D-glucoside on insulin secretion in vivo in diabetic rats and in vitro in isolated rat islets of langerhans. . Pharmazie, 45, 271-273.

Kitazato, K., Wang, Y., \& Kobayashi, N. (2007). Viral infectious disease and natural products with antiviral activity. Drug Discoveries and Therapeutics, 1(1), 14-22.

Kneyber, M. C. J., Mou, H. A., \& Groot, R. D. (2000). Treatment and prevention of respiratory syncytial virus infection. European Journal of Pediatrics, 159, 339-411.

Koukoulitsa, E., Skaltsa, H., Karioti, A., Demetzos, C., \& Dimas, K. (2002). Bioactive sesquiterpene lactones from Centaurea species and their cytotoxic activity against human cells in vitro. Planta Medica, 68, 649-652.

Lonergan, G., Routsi, E., Georgiadis, T., \& etal. (1992). Isolation, NMR studies and biological activities of onopordopicrin from Centaurea sonchifolia. Journal of Natural Products. Journal of Natural Products, 55(2), 225-228.

Ma, S. C., Du, J., But, P. P. H., \& etal. (2002). Antiviral Chinese medicinal herbs against respiratory syncytial virus. Journal of Ethnopharmacology, 79, 205-211.

Medjroubi, K., Benayache, F., \& Bermejo, J. (2005). Sesquiterpene lactones from Centaurea musimomum. Antiplasmodial and cytotoxic activities. Fitoterapia, 76, 744-746.

Orallo, F., Lamela, M., Camina, M., Uriatre, E., \& Calleja, M. (1998). Preliminary study of the potential vasodilator effects on rat aorta of centaurein and centaureidin. Two flavonoids from Centaurea corcubionensis. Planta Medica, 64(2), 116-119.

Özçelik, B., Gürbüz, I., Karaoğlu, T., \& Yeşilada, E. (2009). Antiviral and antimicrobial activities of three sesquiterpene lactones from Centaurea solstitialis L. ssp. solstitialis. Microbiological Research, 164(5), 545-552.

Rusak, G., Krajacic, M., \& Plese, N. (1997). Inhibition of Tomato Bushy Stunt Virus infection using a quercetagenin flavonoid isolated from Centaurea rupestris L. Antiviral Research, 36(2), 125129.

Sathiyamoorthy, P., Lugasi-Evgi, H., Schlesinger, P., \& etal. (1999). Screening for cytotoxic and antimalarial activities in desert plants of the Negev and Bedouin market plants products. Pharmaceutical Biology, 37(3), 188-195.

Schinazi, R. F., Coats, S. J., Bassit, L. C., Lennerstrand, J., Nettles, J. H., \& Hurwitz, S. J. (2009). Approaches for the development of antiviral compounds: the case of hepatitis $\mathrm{C}$ virus. Handbook of Experimental Pharmacology, 189, 25-51.

Sezik, E., Yeşilada, E., Honda, G., Takaishi, Y., Takeda, Y., \& Tanaka, T. (2001). Traditional medicine in Turkey X. Folk medicine in Central Anatolia. Journal of Ethnopharmacology, 75, 95-115.

Shang, X., H, X., H, X., \& etal. (2001). The genus Scutellaria an ethnopharmacological and phytochemical review. Journal of Ethnopharmacology, 128, 279-313. 
Skaltsa, H., Lazari, D., Garcia, B., Pedro, J. R., Sokovic, M., \& Constantinidis, T. (2000). Sesquiterpene lactones from Centaurea achaia, a Greek endemic species: Antifungal activity. Zeitschrift für Naturforschung C, 55(7-8), 534-539.

Smith, D. W., Feankel, L. R., Mathers, L. H., Tang, A. T. S., Ariagno, R. L., \& Prober, C. G. (1991). A controlled trial of aerosolized ribavirin in infants receiving mechanical ventilation for severe respiratory syncytial virus infections. New England Journal of Medicine, 325, 24-29.

Treanor, J., \& Falsey, A. (1999). Respiratory viral infections in the elderly. Antiviral Research, 44, 79-102.

Uzuncar, S., \& Duman, R. (2016). Evaluation of in vitro antiviral activity of Centaurea kotschyi var. decumbens extracts against Herpes Simplex Virus Type 1 (HSV-1). . International Journal of Scientific and Technological Research, 2(2), 20-28.

Wagenitz, G. (1975). In: Davis PH, ed., Flora of Turkey and the East Aegean Islands, (Vol. 5). Centaurea LEdinburgh: Edinburgh University Press.

Wray, S. K., Gilbert, B. E., \& Knight, V. (1985). Effect of ribavirin triphosphats on primer generation and elongation during influenza virus transcription in vitro. . Antiviral Research, 5, 39-48.

Wyde, P. R., Moore-Poveda, D. K., 0'Hara, B., Ding, W. D., Mitsner, B., \& Gilbert, B. E. (1998). CL387626 exhibits marked and unusual antiviral activity against respiratory syncytial virus in tissue culture and in cotton rats. Antiviral Research, 38, 31-42.

Yeşilada, E., Gürbüz, İ., \& Shibata, H. (1999). Screening of Turkish anti-ulcerogenic folk remedies for anti-Helicobacter pylori activity. Journal of Ethnopharmacology, 66, 289-293.

Yeşilada, E., Sezik, E., Fujita, T., Tanaka, S., \& Tabata, M. (1993). Screening of some Turkish medicinal plants for their antiulserogenic activities. Phytotherapy Research, 7, 263-265. 